\title{
Appointment Time: Disability and Neoliberal Workfare Temporalities
}

Karen Soldatic, Centre for Human Rights Education, Curtin University, Australia

Karen Soldatic

Lecturer

Centre for Human Rights Education

Curtin University

Perth, Western Australia

Email: k.soldatic@curtin.edu.au

Acknowledgements: I would like to thank Janaka Biyanwila, Helen Meekosha, Donna Reeve and Russell Shuttleworth for their comments on earlier drafts of this paper. 


\section{Appointment Time: Disability and Neoliberal Workfare Temporalities}

\section{Abstract}

My primary interest in this paper is to reveal the complexity of neoliberal temporalities on the lives of disabled people forced to participate in workfare regimes to maintain access to social security measures and programming. Through drawing upon some of the contemporary debates arising within the social study of time, this paper explicates what Jessop (2008) refers to as the sovereignty of time that has emerged with the global adoption of neoliberal workfare regimes. It is argued that the central role of temporality within the globalizing project of neoliberal workfare and the positioning of disability within these global macro-structural processes, requires the sociological imagination to return to both time as a theme and time as a methodology.

Key words: disability, temporality, neoliberalism, workfare 
Seesaw Margery Daw

Joanna shall have a new master

She shall earn but a penny a day

Because she can't work any faster

\section{Introduction}

This paper seeks to explore the temporal relations of power embedded in neoliberal workfare regimes and the implications for disabled people forced to negotiate workfare to maintain access to social security measures and programming. Through analysing key features of the globalization of neoliberal workfare restructuring and drawing upon casestudy material grounded in the Australian experience, I will argue, in line with Wilson (1999), Adam (2004) and Jessop (2008), that we can no longer ignore the temporal sovereignty of global processes which intersect, compete and override the multiplicity of temporalities operating within neoliberal workfare regimes that shape the biographies of everyday life.

Time is a commanding and complex phenomenon (Adam 2004). While time as a disciplining regime within the capitalist order remains dominant, there is an array of heterogeneous times, and their meaning, significance and interpretation cannot be conflated, collapsed or consumed by a single homogeneous time (Adam 1990, 2004; Glennie and Thrift 1996;

Wilson 1999; May and Thrift 2001; Jessop 2008). As proposed by Glennie and Thrift (1996: 
279) the temporal multiplicity of everyday life 'can no longer be seen as an endless and continuous scale but as a discontinuous and multiple process'. While time is typically presented as linear and/or based upon the clock which, no doubt, has 'infused understanding and changed public and private social relations' (Adam 2004: 133), not all times can be captured in such a mechanical and linear method. Clock time, as a mechanic device of temporal measurement, assumes a universal, objective neutrality, 'cut loose from the temporal rhythms of the body' (Adam 2004: 115). The multiplicity of temporal rhythms thus needs to be contextualized and situated within the multiplicity of temporalities that exist, with their own internal logic, which are constantly negotiated, contested and resisted (Schwanen 2006: 884). A rigorous and critical analysis of temporality needs to identify the multiplicity of times and their patterns of synchronization, continuity, discontinuity and disruption and, more significantly, critically unmask their seemingly competing rhythmic articulations that result in (re)shaping the experience of everyday life (Adam 2004).

Such theoretical accounts of temporality have numerous implications for the realm of disability studies as, too often, the temporal framing of disability has been suggestive of a homogeneous linear construction of past time, present time and some future time (Clear and Gleeson 2001). As an example, the historical temporal depictions of disability, or disability past time, are largely grounded on mechanical clock time. These accounts have situated the past time of disability as being silent and invisible (see Hevey 1992 as an example) or have sought to identify the ways in which disability signifies a particular cultural-historical past time spectacle where disability and its freakery become symbolic of cultural fascinations of the body at, and in, a particular time (see Garland-Thomson 1996). 
While these studies have been important in illuminating the historical locations of disability, they are limited to a linear understanding of time and, therefore, do not take account of the historical multiplicity of temporalities that shape social understandings and rhythmic locations of disability.

Further, in line with this kind of temporal theoretical enclosure, axiomatic models of a linear disability temporality have also developed, such as Finkelstein's (1993) three stages of disability. Finkelstein's three stages of disability is grounded in the linear clock-time model, where past time is represented as invisibility, present time as oppression and finally, a future time which is held as the time of emancipation. In this instance, future time appears representative of an emancipated disabled identity, free from all disabling social constructs. Others, such as Wendell (1996), while acknowledging the changing rhythmic patterns of post-industrial time, have assumed that their own bodily temporal rhythms remain unchanged even as the temporal speed of the workplace has been radically reorganized with the emergent post-industrial temporal landscape. As Glennie and Thrift (1996: 290) suggest, this is a highly problematic argument, as it denies the circulated interactive rhythmic nature of the multiplicity of times which 'become[s] - in time - the very fabric of experience'.

To elucidate the critical relevance of time for disability studies, in this paper, I will empirically focus on the dominant governing technology to emerge under neoliberal workfare regimes, that is, 'the Appointment'. As discussed later in greater detail, the Appointment offers a promising site to explore the temporal sovereignty of neoliberal global workfare 
restructuring and its metamorphosing properties, which impinge upon the lived experience of disability. Articulated in nation-state policy, it assumes a particular temporal hegemony. While structurally shaped, as revealed in the later sections of this paper, the neoliberal workfare Appointment frames and reframes individual biographies and the experience of everyday life, determining access to a range of social supports and services. Drawing upon a range of key state policy documents and in-depth interviews with disabled people from across Australia in late 2006, the paper illustrates that the Appointment has become the key signifier of neoliberal workfare relations and the power hierarchies embedded within them.

\section{Disability, Neoliberal Workfare and Temporal Methodologies}

Geographers have been particularly adept in identifying the spatial relations of globalization, critically engaging with the ensuing processes of neoliberal workfare restructuring (Haylett 2003; Schram et al. 2008). Neoliberal workfare has become the global hegemonic discourse and practice for social policy restructuring (Peck 2001). As note by critical geographers such as Wolch and Deverteuil 2001, neoliberal restructuring has occurred not only at the national level in terms of policy, but also at the level of the street, where workers adopt new welfare practices. While neoliberal workfare's realization and practices are locally distinct, it has become a central component of the globalization of neoliberal regulation (Tickell and Peck 2003).

The central argument within neoliberal workfare debates is that any job is a good job, no matter its conditions or hours of pay (Peck and Theodore 2000: 123). As a condition of 
receiving state welfare benefits, ${ }^{1}$ individuals are now forced to participate in a range of statesponsored labour-market programming to maintain access to social security payments (Peck 2001; Schram et al. 2008; Soldatic and Chapman 2010). As Peck and Theodore (2000) rightly note, the principal aim of these programming measures is to rapidly move workfare recipients into the labour market to diminish the numbers on welfare. In turn, workfare participants spiral through a myriad of workfare spaces and places (Peck 2001). Workfare programmers engage in '[s]ocial practices of morality' (Sayer 2005: 157), coaching workfare participants in neoliberal practices of social embodiment, where their central understanding of citizenship is shaped to reflect the discipline of nascent labour-market norms (Soldatic and Meekosha 2011).

Globally, one of the most common features to emerge with the remapping of labour-market supports in line with neoliberal workfare programming has been the passage of legislative frameworks, where the state has bestowed upon workfare services a set of sanctioning powers (Soldatic and Meekosha 2011). These spaces and places are now endowed by the state with new disciplining powers, where they have the power to 'determine' who maintains access to labour-market programming and supports (Thornton and Marston 2009). Given their new legislative authority to monitor citizens on workfare programs, these service landscapes enact social technologies of surveillance, such as individual compacts, to enforce workforce participation as a duty of citizenship (Bessant 2000). The effects, differentiated by disability, gender, race, class and geo-political positioning enforce citizens into a deepening and enduring web of 'surveillance' landscapes; churning participants through workfare programming that actively seeks to individualize and moralize their 
structural location of disadvantage, marginalization and poverty (Hancock 2004; Soldatic and Pini 2009; Fisher and Reese 2011).

Disabled people have not been exempt from neoliberal workfare restructuring. Indeed, across western liberal democracies, disability, as a socio-political category of state citizenship, has been particularly targeted (Chouinard and Crooks 2006; Grover and Piggott 2010; Soldatic and Chapman 2010). In Canada, the USA, Australia and the UK, state categorization of disability has undergone a process of restratification, where the key criterion to access disability rights and entitlements has been radically reconfigured to reflect new work norms (Wilton and Schuer 2006; Soldatic and Meekosha 2011). In turn, many disabled people, who previously had access to a range of disability social rights and entitlements, have lost their disability status and are now being propelled into open, precarious and contingent forms of work (Wilton 2006; Reeve 2011). Nor have disabled people been exempt from the multitude of workfare programming and individual behavioural technologies that other groups have been forced to endure such as single parents and older workers (see Chouinard and Crooks 2006; Magna et al. 2008).

These nascent processes of disability restratification are pinned to the work test; disability categorization is measured against the temporal flow and speed of the labour market (Soldatic 2009). ${ }^{2}$ The state, to maintain its legitimacy and hide the fluidity of disability categorization within changing work norms, harnesses the hegemonic power of medical technologies and professional knowledge to determine a disabled person's work-capacity 
(Soldatic and Meekosha 2011). The assessment of disability work-capacity, however, is measured against the temporal rhythms, ebbs and flows of the capitalist labour market. As part-time, flexible, casualized and scattered work has become the norm (Hochschild 1997; Cornfield et al. 2001; Crow and Heath 2003), the disability work test has been radically reconfigured to mirror the growing dominance of neoliberal temporal restructuring of the labour market. Thus, hours of work, on a weekly basis, has become the primary determining factor to grant disability status (Soldatic 2009). While the general tendency is to frame disability in terms of labour-market skills and competence, in all, disability is a test of temporal competency, predictability and synchronicity.

State neoliberal workfare restructuring of 'disability status', in line with new labour-market temporal norms, has resulted in the development of a multiplicity of new classes of disability, from the 'really' disabled and thus deserving of state welfare, through to the 'just disabled' who are positioned as being more amenable to part-time, casualized, flexible, precarious labour markets. ${ }^{3}$ As a prominent UK disability activist recently suggested, neoliberal disability restratification means that disabled people are 'all going to have to mud wrestle to prove who is most disabled and therefore most deserving, and throw the losers into the gutter' (Disability Bitch 2010). 'The losers to be thrown into the gutter' have become a group of people 'living in between' (Lightman et al. 2009: 2), not disabled enough to be 'deserving' of state welfare, nor 'able-bodied enough' to be considered fully ablebodied by the neoliberal labour market. A precarious existence awaits this group, further entrenching their structural position of poverty as a 'not severely enough' nor 'able-bodied enough' disabled person. International research has noted the effects are more pronounced 
for women with disabilities due to their labour market exclusion because of their timeintensive care responsibilities, resulting in higher levels of poverty (Salthouse 2005).

Such stratification processes, as Reeve (2011: np) poignantly contends, means that disabled people are 'being forced to define oneself in terms of what one is unable to do and reproduce the incapable body/mind to identify themselves as a disabled person incapable of work [original emphasis]'. ${ }^{4}$ Thus, disability social embodiment, under neoliberal workfare regimes, is not only psychologically disabling for the individual concerned, but actively seeks to normalize and individualize disabled people's structural location of 'worklessness' and the subsequent position of exclusion, marginalization and poverty. Disabled people's 'workless' status has now become inscribed not only on their bodies, but also within, as they are forced to internalize social practices of morality (Soldatic 2009) that situate their bodies and minds as useless and waste (see Hughes et al. 2005; Soldatic and Meekosha 2011).

All of this research points to the ways in which disabled people undergo a qualitative process of sorting; states divide out and classify bodies into hierarchical socio-political formations that are in line with the temporal demands, ebbs and flows of the capitalist labour market. Gleeson (1999) suggests that the temporal reification of disability for social classification regimes has long played a role in processes of disability stratification where access to social security measures, such as the mobility allowance in Australia, is tied to hours of work. The experience of 'disability' with the emergence of neoliberal workfare regimes illuminates the temporal sovereignty of processes inherent in neoliberal workfare regimes. State technologies of surveillance and the successive moral, social and political disciplining 
regimes are performing a state 'service', of classifying bodies into temporal hierarchies enabling states to mount arguments of legitimacy for redistribution measures targeting a particular class of people (Soldatic 2009). Disability is the default category for these state redistributive social provisioning measures and processes, and up until the neoliberal workfare turn, has largely remained unquestioned. ${ }^{5}$

The conceptualization of disability as a signifier for neoliberal workfare temporality echoes arguments raised in EP Thompson's (1967) seminal essay 'Time, Work-Discipline and Industrial Capitalism'. Thompson's central argument tried to capture the temporal flow of capitalism and the way in which mechanical time-disciplines of the workplace become socialized, internalized and, hence, naturalized. As noted by Glennie and Thrift (1996), Thompson sought to critically analyse the ways in which the capitalist workplace disciplines bodies into new industrial temporalities, with industrialised time becoming normalized and moralized. Bodies internalize the speed of the industrial workplace, reproducing these temporal rhythms in everyday life. Thompson's argument foreshadowed the ways in which nation-states, under neoliberal workfare restructuring, have drawn upon a range of mechanic clock time to discipline the body.

While Thompson's argument of industrial time is clearly apparent in the stratification of disability to enforce nascent work norms within neoliberal workfare regimes, as Adam (1990, 1995, 2004), Glennie and Thrift (1996), Wilson (1999), May and Thrift (2001) and Jessop (2008) all suggest, we need to consider the multiplicity of times that occur simultaneously. For disabled people, their historical temporal discursive positioning as a 
class of workless peoples within full-time labour markets has now shifted within the public imaginary, where the state has actively developed a range of moral strategies that situate disability within the new temporal norms of work. In turn, public opinion has shifted against state redistributive social provisioning measures for those people defined as 'just disabled' (see Scope 2011). The state's moral framing, resting upon new temporal regimes of work, represents this class of disabled people within the public imaginary as workshy scrounges, defrauding the welfare system (Grover and Piggott 2010; Soldatic and Pini 2012).

These discursive framings of disabled people as morally fraudulent have all been coded to imitate the temporal disciplines of the neoliberal labour market. The implicit meaning within these temporal discursive practices is to reinscribe, reimagine and reshape social understandings of the prior welfare state contract and to hide the socio-relations of power deeply embedded within it. These discursive strategies are reflective of what Soldatic (2009) articulates as temporal discursive markers, which signify the new temporal disciplines of the neoliberal economy. In the case of Australia, the new norms of part-time, casualized, flexible and scattered work not only underpin state constructions of disability status, but have also been pivotal to building support for neoliberal state workfare restructuring of disability. The key state policy document, Participation for a More Equitable Society (2000), referenced temporal discursive markers throughout, culminating in more than 112 citations.

In the case of disability, the state's harnessing of temporal discursive markers within the Report were not only drawn upon to flag new work disciplining regimes in line with 
neoliberal workfare restructuring, but were also deeply enshrouded with moral and symbolic meaning. Thus, temporality more explicitly operated through three social understandings of time. First, temporality was pivotal to the disability classification process to enforce new work norms among disabled people in line with neoliberal labour-market restructuring. Secondly, temporality was positioned symbolically to signify the state's neoliberal restructuring as a process of state transformation for some future time. Here, the temporal symbolism signified ideas of national progress where time is imbued with national meaning through discursively positioning some future time with discourses of improvement. A nation moving itself and its people forward became a moral crusade for the benefit of all within the polity (see Hetherington 2001). And finally, inter-related to the previous point, temporality was pivotal as a moralizing citizenship discourse, building support within the polity for the radical reconfiguration and transformation of state-citizenship relations. With the temporal framing of state-citizen relations, nation-states perpetuated the myth of the rights and responsibilities discourse central to neoliberal governance, where rights are only granted in 'exchange' with citizen responsibilities. In this instance, time was used to determine 'exchange value' as the key moderator of state-citizen relations (see Wilson 1999). Therefore, rights as realized in neoliberal citizenship has been reconstructed around work, where work has become the hegemonic responsibility which must be achieved for individuals to realise their citizenship rights.

All of these temporalities were not only underpinned by the temporal velocity of the evolving neoliberal political economy but, just as significantly, encapsulated a multiplicity of times. In terms of disability, as illustrated above the active development of a state campaign 
to promulgate new social understandings of disability drew upon a range of socio-political understandings of time; that is, circulating new social understandings of disability for and in some future time which contained few, if any, references to how disability was understood in past time or the present. Disability in this future time was not only radically reconfigured to shore up classification regimes in line with neoliberal industrial temporal disciplines, but also to symbolically impose ideas of national improvement and progress, where this future national framing of disability was representative of a mobile and transformational nationstate.

To concur with Jessop (2008: 184) we 'need to make a thematic and methodological temporal (re)turn to readdress the one-sided concern with space with globalisation [original emphasis]' that has emerged over recent years. While Jessop's arguments are aimed at the broader social sciences, they resonate strongly within the field of disability where there has been limited thematic or methodological engagement with time. In identifying with Jessop's call, I will now turn to disability temporalities and the multiplicity of new 'times' emergent in neoliberal workfare regimes. In the following section, which explicitly targets 'the Appointment' - a key governing technology to emerge with the globalization of neoliberal workfare regimes - the empirical analysis articulates the multiple, contested, resisted and negotiated temporalities that emerge with the neoliberal workfare appointment. While the Appointment is clearly positioned within neoliberal workfare public policy as mechanical clock time, and appears as universal, objective and neutral, the critical analysis reveals the multiplicity of temporalities embedded within the time/s of the Appointment. Finally, this analysis illuminates the way in which the Appointment, as an abstract construction of time, 
becomes contextualized, particularized and grounded within the rhythmic temporalities of the lived experience of disability.

\section{Appointment Time: Disability and Neoliberal Temporal Governance}

They think that we should be living our lives to their time.

Juliet, Perth

The idea of the Appointment is clearly associated with the hegemony of clock time and calendar time. To set an appointment, all parties involved, whether this be a combination of two people or more, are required to 'agree to' a specified time. This specified time, the Appointment, is not only standardized by the clock but is also set within a day, week, month and year. This time is set for some time in the future. Of course, this standardization of time via the clock and the calendar makes the setting of an appointment appear relatively easy, as it assumes that the individuals involved are engaged in socio-relations of equal negotiation, where each is able to readily express their preference for a particular time. The individuals involved then set the Appointment for a mutually agreeable time, which is seemingly convenient, fitting and suitable for all concerned.

This depiction of the Appointment would be readily identifiable to most readers of this paper. Frequently, we are all involved in arranging an appointment, even multiple appointments, where we have gone through our diaries and suggested a multitude of possible times, which are then negotiated down to a single time. On some occasions, there 
is no mutually agreeable time and someone misses out on participating in the Appointment. In other instances, some of the initial negotiating members are unable to attend as per the original time specified and, in turn, the original appointment time is either cancelled or rescheduled. If rescheduled, this is a newly negotiated, and somewhat mutually agreeable, time in the future. There are, of course, those whose sense of time is not fully synchronized in mechanic clock and calendar time, who frequently arrive late or not at all.

However, what if the individuals involved in the Appointment do not actually 'set' the Appointment? And what happens when our bodily temporal patterns are unable to be synchronized with the multiplicity of rhythmic temporal patterns of everyday life with this forced appointment time? Many of us have experienced this forced temporal coordination of our daily lives, particularly the clashing of work appointments with home-life commitments. These questions no doubt critically engage with the framing of the Appointment as a mutually consensual time, where individuals are freely engaged in the negotiated practice of synchronizing the multiplicity of times to which they are embedded.

As alluded to throughout this paper, the Appointment has become a critical component of neoliberal workfare regimes. With the globalization of neoliberal workfare, citizens with disabilities have been forced to participate in a myriad of appointments. Attending these appointments has become part of evaluative assessment of citizenship, where individuals in receipt of workfare are expected to show up on time. According to Schwanen (2006: 884), the Appointment not only signifies the 'conception of time represented by the clock' but, more significantly, is underpinned by the notion of being 'on time', which is situated as 'objectively quantifiable'. It is assumed the people involved are in a position to control and 
synchronize the competing set of temporalities managed in everyday life to make the Appointment. The Appointment therefore appears as 'universal' in socio-temporal understandings. Adam (2004: 43) argues this imbues the appointment time with designs of 'predictability and calculability'. Thus, the Appointment, clearly conceptualized through clock time and the calendar, sits above the multiplicity of times operating across the multiplicity of scales, spaces and places. In turn, the Appointment begins to take on a life of its own, commanding temporal rhythmic control, synchronization and continuity of other spheres, including that of the body.

Governing by the Appointment has become one of the central mechanisms of Australian neoliberal workfare regimes and has been largely replicated in neoliberal structures of governance within the UK, the USA and Canada (Soldatic 2009). The Appointment is distinguishable because it has great importance in positioning the nation, for some future time, when all are bequeathed with neoliberal work time. As part of the temporal regulatory regime, workfare recipients are required to meet allocated appointment times, set by the nation, to maintain access to social security and disability supports and payments. The Appointment, and the setting of the Appointment at some time in the future, illuminates social relations of power, where citizens in receipt of welfare are forced to meet a multiplicity of competing appointment times to maintain access to previously held entitlements as a right of citizenship.

In Australia, the national significance of the Appointment is enshrined in nation-state legislation. ${ }^{7}$ Workfare recipients are required by law to attend a set of required 
appointments and, thus, the Appointment has become the key governing criterion of statedisability citizen relations of exchange. Citizenship is measured against one's participation with these appointments, which was expressed by Minister Andrews, the minister responsible for neoliberal workfare legislation restructuring in Australia, when he stated in parliament that:
A job seeker without a record of repeated non-compliance who commits a participation failure, such as missing an interview with an employment service provider, will be given the opportunity to avoid any financial penalty by quickly re- engaging with that provider [emphasis added]. (Hansard, Australian Parliament, 2005: 7).

The Appointment, or the missing of an appointment, as outlined in the ministerial statement above, has become a key temporal mechanism of the technologies of neoliberal governance. In the statement, the minister clearly depicts the Appointment as central to neoliberal disciplining techniques for workless people.

Those disabled people who no longer qualify as being disabled enough for state welfare with the reconfiguration of the temporal work test are also required to endure the temporal neoliberal disciplining regime of the Appointment. Disabled people are highly cognizant of the disciplining role of the Appointment within neoliberal workfare relations, and its implication of having to make their bodies mobile to move through a multiplicity of workfare spaces and places. Marie, a woman with a vision impairment living in an urban area of Sydney, clearly identifies the Appointment as a temporal technology and surveillance regime 
when she states that: 'It was always geared towards shunting us off to employment agencies and a lot of referrals, paperwork.' Further, as Marie suggests, the Appointment signifies the mobility of bodies through a multiplicity of spaces and places. While disabled people must endure the surveillance practices of workfare services and programming, as Marie's dialogue suggests, it is the Appointment which determines the flow and movement of the body.

Josephine, a woman in her early twenties with a vision impairment living in an outer suburb of Sydney, has experienced multiple appointments with the advent of neoliberal workfare in Australia. She has experienced the cyclical rhythmic repetitiveness of the array of neoliberal temporalities and highlights the ways in which the Appointment, and the corresponding and continuous appointments, disregard the previous spatial locality and the spatial relations embedded within them. Josephine describes this process when she states that: 'This was the third interview at which I've answered questions about the type of work I'm seeking and how my vision impairment and other factors will affect my employment. ' As Josephine articulates, disabled people are churned through a web of repetitive surveillance structures that emerge with the Appointment under neoliberal workfare regimes. The temporal repetition of attending the multiple appointments also signifies Reeve's comments cited earlier, where a disabled person is constantly put in a position of having to define herself by what she is 'unable to do'. Josephine notes the way in which temporal structures, and their continuous temporal flow, result in the internalization of one's impairment as the effect on their workless status, naturalizing labour-market structures of exclusion, marginalization and discrimination. 
Josephine's experience of the Appointment, as a temporal disciplining regime, also signifies the way in which disabled people's movement through a multitude of spaces disregards the temporal patterning of processes that appear when temporal regimes are framed as numbers, that is, the third time. Josephine's repetitive experience of the Appointment, embedded within neoliberal workfare regimes, is clearly suggestive of what Adam (2004) refers to as the patterning of temporal processes as they begin to be pictured as numbers. The numbering of temporal patterns acts to shade and hide the temporal relations of power, where patterning is constructed and controlled outside of those biographies directly affected. Once temporality is signified as a number, the process of patterning as repetition becomes naturalized, as it undertakes a qualitative reconfiguration, which frames the movement through a range of spaces and places as an inevitable outcome of a disabled person's workless structural location. Thus, the Appointment binds the time of citizens to the new temporal disciplining regimes of neoliberal citizenship. The temporal pace, flow and pattern of each citizen is bound to a nationally stipulated and coordinated time, which overrides local temporalities situated, positioned and mobilized within local landscapes. Should we expect all bodies to be synchronized by a continual routine of clock time and calendar time, and should we use this as the central measurement of rights to citizenship?

Further, the assigning of the Appointment at the national scale is used as an efficient, quantifiable and readily identifiable unit of measurement. The purpose here is for the nation-state to override local spatial contingencies that may directly compete, contest or resist national time. As such, workfare services and programmers are enabled to easily operationalize their sanctioning powers, endowed by the state, as they can measure 
individual compliance against the national Appointment time. The Appointment, as both a neoliberal disciplining technology and a neoliberal unit of measurement, is easily implemented across a multiplicity of spaces and places, in turn overriding local time-space practices, particularities and specificities, such as the cultural practices of time for disabled people living in rural and remote regions. The Appointment as a signifier of time and its temporal sovereignty has commanded a multiscalar presence, seemingly universal, yet invisible in its power.

This is best exemplified when we explore the temporal impact on the individual biographies of disabled people within the private realm. As discovered by Naomi, a woman living with cerebral palsy in an inner urban area, if the spatial relations of exclusion are the lived reality of disability with your particular impairment, then the temporal sovereignty of the Appointment has the velocity to surmount these spatial boundaries; the Appointment comes to you. The workfare Appointment has its own rhythmic logic which is highly mobile as Naomi discovered when the Appointment came to her home: 'She turned up at my door with another staff member from the agency who I had never met before; these two women sat in my living room and proceeded to lecture me for 45 minutes on the realities of looking for work when you have a disability.'

Naomi's experience, while appearing unusual, is in fact exemplary of the lived experience of disability within neoliberal workfare regimes and the temporal rationalities that position disabled people's structural location of discrimination, marginalization and poverty as 
inevitable and natural. This is due to the symbolic representation of disabled people within the Appointment itself. The assignment of a moral evaluative judgement is implicit within the minister's appointment time. The Appointment, or more significantly in the minister's parliamentary statement above, the missing of an appointment, reflects the moral economy of temporal relations in neoliberal workfare regimes as Minister Andrews positions the missing interview as a 'rational calculable action' (Adam 2004). The individual's noncompliance to the clock time, marking out the allocation of the Appointment as a reasonable and rational act, is moralized as an individual failure of national duty. ${ }^{8}$

Skeggs (2004: 82) suggests that 'Those who cannot perform their state-defined "duty" are thus morally suspect'. The positioning of the Appointment is not only a temporal governing technology and disciplining regime, but also acts to enshroud the welfare recipient with moral meaning which embodies a moral discourse of suspicion. The minister's juxtaposition of the possibly good welfare recipient stands in contrast to those citizens who have 'repeated non-compliance'. As Adam (2004) suggests in her reading of Weber's work on temporality, the 'proper keeping of time ... had become a duty, an integral part of Protestant righteous conduct'. Under neoliberal workare, compliance is a duty of citizenship (Eardley 2005) and there is no consideration that for disabled people to comply with neoliberal workfare appointments, they are largely reliant upon the supports and services of home support workers and/or readily accessible public transport to get to the appointment on time. And in framing citizenship within the conditionality of neoliberal workfare, the 'job seeker without a record of non-compliance' is able to seek redemption if their mistake is rectified 'quickly'. The morally fallen can seek nation-state forgiveness; however, this is 
dependent on a temporal moral evaluative judgement, where speed becomes the measurement of morally good behaviour.

The imposition of the Appointment within workfare regimes has radical implications for many disabled people living on workfare payments. The pace of the impaired body encompasses a set of complex temporalities of time-intensive practices of self-care (Dowse et al. 2010). As Larson and von Eye (2010) have found, the temporality of the body has a direct correlation to participation. Marguerite, a woman in her 60 s, best illustrates this situation when she describes her morning routine and her preference for Sundays, a nonwork day:

The thing I like about Sundays is that I don't have to take a shower as I don't have to go out of the house. You able-bodied people don't know how hard it is to take a shower, transferring from my chair to the seat and then ... how cold it is and trying to keep myself from getting a chill because it takes so long to dry off and get changed.

Further, there are not only the temporal complexities of having to synchronise one's own rhythmic processes, but for women with disabilities in particular, who have time-intensive caring responsibilities for themselves and others (Soldatic and Meekosha 2011), rhythmic synchronization requires negotiating a crowd of temporalities. Jennifer, a young woman with a mental illness living in an outer urban area, describes the potential impossibility of complex temporal management, as required under neoliberal workfare temporal disciplining regimes, when she highlights the personal temporal conditions she is required to negotiate: 
It's pretty hard when I have to look for work. It's alright if I've got day care five days per week. But I would like to have some work, it's alright for me to work but the hours they want me to work, I can't work. They want me to work full-time, from 9 to $5 \mathrm{pm}$. But my son's childcare closes at $6 \mathrm{pm}$, so there's no way that I can work those hours.

Jennifer, a woman with a disability living on a workfare payment as she no longer qualifies for disability, is expected to be highly competent in the juggling of the multiplicity of temporalities that she traverses as part of her lived experience. While there has been extensive feminist research on time (see Odih 2003), and the implications of the neoliberal reconstruction of time (see Ladner 2009; Wolch and Deverteuil 2001), this work has little nuanced understanding of the temporal competence required of women with disabilities, particularly for those who are forced into workfare programming. Jennifer is not only required to control the temporal rhythmic flow of her own body, but also coordinate this with her son's care which is then forced to be synchronised with the Appointment as a requirement of maintaining access to workfare programming, services and payments. Thus, Jennifer is required to not only temporally negotiate care for herself and care for others, but also to prioritize care, albeit coerced, for the nation.

The Appointment, while appearing as a neutral, rational, calculable action, is in fact a social relation of power. Its temporal structure appears quantifiable but is actually qualitatively shaped and framed by the social relations of power in which it is embedded. As noted throughout this section of the paper, the application of the Appointment has become a key governing technology with the global emergence of neoliberal workfare. More pertinently, the controlling of the Appointment, that is, who sets the appointment time, why it is set and 
how it is set, is endowed with assumptions. These assumptions act to hide the temporal relations of power which are deeply embedded within the Appointment itself.

The Appointment, while used as a temporal disciplining regime, is also harnessed by the nation-state as an evaluative unit of measurement, drawn upon to not only shape sociopolitical understandings of disability, but more poignantly to position rights to citizenship, as a socio-political relationship of exchange. Part of this process encapsulates the Appointment with a specific moral symbolism, where disability is framed to be representative of a transformational national time with the advent of neoliberal restructuring. Disabled people, attending prescribed workfare appointments, are deemed morally worthy of nation-state support as part of the exchange integral to neoliberal workfare relations. Here the disabled workfare recipient with their attendance at the Appointment is defined by their proper service to the nation.

Finally, while the Appointment presents itself as readily quantifiable and, in turn, relatively reasonable, in effect it denies the required synchronization of the multiplicity of times which disabled people negotiate, shape and live as part of their everyday practice such as rearranging personal care, doctors appointments and domestic assistance. In fact, as the participants of this study present, they are in fact required to subsume all other temporal rhythmic harmonization to the Appointment time of the nation. The effects not only override the temporal rhythms of their bodies, but disabled people, and particularly women with disabilities, are also required to become highly competent in the efficient management of an array of complex temporalities. Thus, the Appointment, while appearing as a single 
unit of time, is in fact riddled with a multiplicity of rhythmic processes of synchronization. In turn, for disabled people, the temporal implications consume the temporal rhythms of their bodies, which become decontextualized, removed and forever moving, from the landscapes in which they are embedded.

\section{Conclusion}

My primary interest in this paper has been to reveal the complexity of temporalities on the lives of disabled people forced to negotiate neoliberal workfare regimes. Through drawing upon some of the contemporary debates arising within the social study of time, this paper has been able to explicate what Jessop (2008) refers to as the sovereignty of time that has emerged with global neoliberal workfare regimes. As identified throughout, the central role of temporality within the globalizing project of neoliberal workfare and the positioning of disability within these global macro-structural processes, requires the sociological imagination to return to both time as a theme and time as a methodology (see Jessop 2008).

As argued by Jessop (2008) and also Adam (2004), we need to position more succinctly the role of temporality, both as a thematic topic of explication and as a methodology, in our analysis of social understandings of disability. As presented in the final section of this paper, time, as both a theme and a methodology, has lived implications for disabled people. The harnessing of temporality, as a structural temporal disciplining regime, a unit of measurement and as a moral category of citizenship, shapes the experience of biography that is lived in the space of the everyday. Through critically analysing the temporal structural processes embedded in macro-structural processes of social change, we can identify and 
elucidate the disability social relations of power which mobilize temporality's sovereignty for its own positioning within the national scale.

The lived ramifications for disabled people, as they are expected to surmount the temporal rhythms of the body for the nation, are very real, as they are required to negotiate these mobilized temporal technologies of governance. Further, the effects are highly gendered, as disabled women are required to synchronize the complex temporalities that emerge with care-giving responsibilities often being both care recipients and care givers. Thus, time, and its socio-political positioning, is lived at the level of biography. 


\section{Notes}

1 I use the term benefits here rather than entitlements to capture the ways in which social security allocations are no longer positioned as a right of citizenship under neoliberal state formations. As Peck (2001), Goodin (2002) and Moss (2006) all denote, access to these previously held citizenship entitlements (come benefits) is now premised on a relationship of exchange with the performance of citizenship duties. This discursive and material shift has been consistent across the UK, USA, Canada and Australia.

2 As noted by numerous disability scholars, such as Stone (1981), Oliver (1990), Gleeson (1999), Roulstone and Barnes (2005), Barnes and Mercer (2010), and Soldatic and Meekosha (2011), the emergence of the Poor Law Act (1834) in the UK with capitalist industrialization resulted in new classification regimes, where 'disability' became the site for the state to sort out bodies to establish a class of citizens entitled to state welfare, or what is more commonly referred to as the 'deserving poor'. To paraphrase Soldatic (2009), this positions disability in highly contradictory terms, a deeply stigmatizing social privilege where disabled people have been historically forced to 'swap' the discipline of the capitalist labour market for the harsh conditions of the workhouse.

3 Further, the attribution of being 'just' disabled with part-time, casualized, contingent work denies the social value of disabled people's participation in well-paid, stable and secure part-time employment while maintaining continued access to disability social entitlements. Unlike neoliberal conceptualizations of disability, such a process would recognize the extensive necessary 'full-time' costs and 'time-intensive' practices of selfcare, of living with an impairment in a disabling society (Barnes and Mercer 2005; Dowse et al. 2010).

4 Reeve draws upon Price and Shildrick (1998) here to situate her argument.

5 The social sciences are not exempt from these claims, which becomes fairly evident when we consider the under-representation of disability in sociological explorations of the diverse arrays of human experience.

6 This count of temporal markers does not include discursive temporal expressions that refer to events in time, such as 'in the last eight years' or 'continuing'.

7 The Appointment, as a central feature of Australian neoliberal workfare regulations, is captured within the Australian government's Welfare to Work Act 2005, which was passed in parliament in mid-December 2005. The passage of the act occurred within 24 hours of radical labour-market deregulation, confirming Peck's (2001: 49) observations that the nexus between the labour-market and welfare regimes is perpetually constructed and reconstructed.

8 As noted by Barbara Adam (2004) in her discussion on Weberian notions of time, one's strict management of time signified one's service to God. It is not difficult to identify how this has been extended to the nation-state under neoliberal workfare regimes, as it readily reflects the positioning of the Appointment within the nation-state at a time when service to the nation is framed through work participation. 


\section{References}

Adam B (1990) Time and Social Theory. Polity Press: Cambridge.

Adam B (1995) Timewatch: The Social Analysis of Time. Polity Press: Cambridge.

Adam B (2004) Time. Polity Press: Cambridge.

Barnes C and Mercer G (2005) Disability, Work and Welfare: Challenging the Social Exclusion of Disabled People. Work, Employment and Society 19(3): 527-45.

Barnes C and Mercer G (2010) Exploring Disability, $2^{\text {nd }}$ ed. Polity Press: Cambridge.

Bessant J (2000) Civil Conscription or Reciprocal Obligation: The Ethics of 'Work-for-theDole'. Australian Journal of Social Issues 35(1): 15-33.

Chouinard V and Crooks V (2006) 'Because they have all the power and I have none': State Restructuring of Income and Employment Supports and Disabled Women's Lives in Ontario. Disability and Society 20(1): 19-32.

Clear M and Gleeson B (2001) Disability and Materialist Embodiment. Journal of Australian Political Economy 49(1): 34-55.

Cornfield D, Campbell K and McCammon H (eds) (2001) Working in Restructured Workplaces: Challenges and New Directions in the Sociology of Work. Sage: Thousand Oaks, CA.

Crow G and Heath S (eds) (2002) Social Conceptions of Time: Structure and Process in Work and Everyday Life. Palgrave Macmillan: London.

Disability Bitch (2010) Blame it on Disability Bitch. Ouch! 23 June 2010. BBC: London. URL (accessed 21 August 2010): http://www.bbc.co.uk/ouch/opinion/b1tch/db_emergency_budget_2010.shtml

Dowse L, Frohmader C and Meekosha H (2010) Intersectionality: Disabled Women. Eastreal P (ed) Women and the Law in Australia, pp. 249-68. LexisNexis: Sydney.

Finkelstein V (1993) Disability: A Social Challenge or an Administrative Responsibility. Swain J, Finkelstein V, French S and Oliver, M (eds) Disabling Barriers - Enabling Environments, pp. 33-44. Sage: London.

Fisher T and Reese E (2011) The Punitive Turn in Social Policies: Critical Race Feminist Reflections on the USA, Great Britain and Beyond. Critical Sociology 37(2): 225-36.

Garland-Thomson R (ed) (1996) Freakery: Cultural Spectacles of the Extraordinary Body. New York University Press: New York, NY. 
Gleeson B (1999) Geographies of Disability. Routledge: London.

Glennie P and Thrift N (1996) Reworking E. P. Thompson's 'Time, Work-Discipline and Industrial Capitalism'. Time and Society 5(3): 275-99.

Goodin R (2002) Structures of Mutual Obligation. Journal of Social Policy 31(4): 579-96.

Grover C and Piggott L (2010) Disgusting! Understanding Financial Support for Disabled People in the UK. Paper presented at the Disability Studies 5th bi-annual conference, 7-9 September. Lancaster University, Lancaster.

Hancock A (2004) The Politics of Disgust: The Public Identity of the Welfare Queen. New York University Press: New York, NY.

Haylett C (2003) Remaking Labour Imaginaries: Social Reproduction and the Internationalising Project of Welfare Reform. Political Geography 22(7): 765-88.

Hetherington K (2001) Moderns as Ancients: Time, Space and the Discourse of Improvement. May J and Thrift N (eds) Timespace: Geographies of Temporality, pp. 49-72. Routledge: London.

Hevey D (1992) The Creatures Time Forgot. Routledge: London.

House of Representatives (2005) Official Hansard. Commonwealth of Australia: Canberra. 9 November 2005.

Hughes B, McKie L, Hopkins D and Watson N (2005) Love's Labours Lost? Feminism, the Disabled People's Movement and an Ethic of Care. Sociology 39(2): 259-74.

Jessop B (2008) State Power. Polity Press: Cambridge.

Ladner S (2009) 'Agency time': A Case Study of the Postindustrial Landscape and its Impact on the Domestic Sphere. Time and Society 18(2-3): 294-303.

Larson E and von Eye A (2010) Beyond Flow: Temporality and Participation in Everyday Activities. American Journal of Occupational Therapy 64(1): 152-63.

Lightman E, Vick A, Herd D and Mitchell A (2009) 'Not disabled enough': Episodic Disabilities and the Ontario Disability Support Program. Disability Studies Quarterly 29(3): 1-9.

Magna S, Parish S and Cassiman A (2008) Policy Lessons from Low-income Mothers with Disabilities. Journal of Women, Politics and Policy 29(2): 181-206.

May J and Thrift N (2001) Timespace: Geographies of Temporality. Routledge: London.

Moss J (2006) 'Mutual Obligation' and 'New Deal': Illegitimate and Unjustified. Ethical Theory and Moral Practice 8(1): 87-104. 
Odih P (2003) Gender, Work and Organisation in the Time/Space Economy of 'Just-in-Time' Labour. Time and Society 12(2-3): 293-314.

Oliver M (1990) The Politics of Disablement. Macmillan: London.

Peck J and Theodore N (2000) 'Work first': Workfare and the Regulation of Contingent Labour Markets. Cambridge Journal of Economics 24(1): 119-38.

Peck J (2001) Workfare States. The Guildford Press: New York, NY.

Price J and Shildrick M (1998) Uncertain Thoughts on the Dis/abled Body. Shildrick M and Price J (eds) Vital Signs: Feminist Reconfigurations of the Bio/logical Body, pp. 224-49. Edinburgh University Press: Edinburgh.

Reeve D (2011) Psycho-emotional Disablism: The Missing Link? Watson N, Thomas C and Roulstone A (eds) Routledge Handbook of Disability Studies. Routledge: London (In press).

Reference Group on Welfare Reform (2000) Participation for a More Equitable Society (McClure Report). Australian Government: Canberra.

Roulstone A and Barnes C (2005) Working Futures? Disabled People, Policy and Social Inclusion. Policy Press: Bristol.

Salthouse S (2005) Jumping Through Hoops: Welfare and Industrial Relations Reform Implications for Women with Disabilities. Paper presented at the What Women Want Workshop on behalf of Women with Disabilities Australia. URL (consulted 10 February 2009): http://www.wwda.org.au/w2wjuly05.htm

Sayer A (2005) The Moral Significance of Class. Oxford University Press: Oxford.

Schram S, Fording R and Soss J (2008) Neo-liberal Poverty Governance: Race, Place and the Punitive Turn in US Welfare Policy. Cambridge Journal of Regions, Economy and Society 1(1): 17-36.

Schwanen T (2006) Arriving 'on time', but what is 'on time?' Geoforum, 37(3): 882-94.

Scope (2011) Deteriorating Attitudes Towards Disabled People. Scope: London. URL (consulted 17 May 2011): http://www.scope.org.uk/news/attitudes-towards-disabledpeople-survey

Skeggs B (2004) Self, Class, Culture. Routledge: London.

Soldatic K (2009) Disability and the Australian Neoliberal Workfare State. PhD thesis, University of Western Australia. 
Soldatic K and Pini B (2009) The Three Ds of Welfare Reform: Disability, Disgust and Deservingness. Australian Journal of Human Rights 15(1): 76-94.

Soldatic K and Chapman A (2010) Surviving the Assault? Australian Disability Movement and the Neoliberal Workfare State. Social Movement Studies 9(2): 136-154 (Special issue on Australian social movements).

Soldatic K and Meekosha H (2011) Disability and Neoliberal State Formations. Watson N, Thomas C and Roulstone A (eds) Routledge Handbook of Disability Studies. Routledge: London (In press).

Soldatic K and Pini B (2012) Change or Continuity? The Rudd Government and the Case of Disability. Social Policy \& Society 11(2) (In press).

Stone D (1981) The Disabled State. Temple University Press: Philadelphia, PA.

Thompson, EP (1967) Time, Work-Discipline and Industrial Capitalism. Past and Present 38(1): 56-97.

Thornton S and Marston G (2009) Who to Serve? The Ethical Dilemma of Employment Consultants in Nonprofit Disability Employment Network Organisations. Australian Journal of Social Issues 44(1): 73-89.

Tickell A and Peck J (2003) Making Global Rules: Globalisation or Neoliberalisation? Peck J and Wai-chung Yeung H (eds) Remaking the Global Economy: Economic-Geographical Perspectives, pp. 163-81. Sage: London.

Wendell S (1996) The Rejected Body: Feminist Philosophical Reflections on Disability. Routledge: New York, NY.

Wilkin P (1997) New Myths for the South: Globalisation and the Conflict between Private Power and Freedom. Thomas C (ed.) Globalisation and the South, pp. 23-48. St Martin's Press: New York, NY.

Wilson H (1999) Time, Space and Value: Recovering the Public Sphere. Time \& Society 8(1): 161-81.

Wilton R and Schuer S (2006) Towards Socio-spatial Inclusion? Disabled People, Neoliberalism and the Contemporary Labour Market. Area 38(2): 186-95.

Wilton R (2006) Working at the Margins: Disabled People and the Growth of Precarious Employment. Potherier D and Devlin R (eds) Critical Disability Theory, pp. 129-50. UBC Press: Vancouver.

Wolch J and Deverteuil G (2001) New Landscapes of Urban Poverty Management. May J and Thrift N (eds) Timespace: Geographies of Temporality, pp. 149-68. Routledge: London. 
